\title{
Socio-Economic Factors Influencing Travel Decision-Making of Poles and Nepalis during the COVID-19 Pandemic
}

\author{
Michał Roman ${ }^{1}\left(\mathbb{D}\right.$, Kumar Bhatta $\left.{ }^{2, *} \mathbb{(}\right)$, Monika Roman ${ }^{3}{ }^{(0)}$ and Prakash Gautam ${ }^{4}(\mathbb{D}$ \\ 1 Department of Tourism, Social Communication and Counselling, Institute of Economics and Finance, \\ Warsaw University of Life Sciences, Nowoursynowska 166, 02-787 Warsaw, Poland; \\ michal_roman@sggw.edu.pl \\ 2 Institute for Asian and Oceanian Studies, Kyushu University, Motooka 744, Nishi-ku, \\ Fukuoka 819-0395, Japan \\ 3 Department of Logistics, Institute of Economics and Finance, Warsaw University of Life Sciences, \\ Nowoursynowska 166, 02-787 Warsaw, Poland; monika_roman@sggw.edu.pl \\ 4 Faculty of Business Administration, Soka University, 1 Chome-236 Tangimachi, Hachioji, \\ Tokyo 192-8577, Japan; gautam@soka.ac.jp \\ * Correspondence: kumar2bhatta@gmail.com
}

Citation: Roman, M.; Bhatta, K.;

Roman, M.; Gautam, P.

Socio-Economic Factors Influencing Travel Decision-Making of Poles and Nepalis during the COVID-19 Pandemic. Sustainability 2021, 13, 11468. https://doi.org/10.3390/ su132011468

Academic Editor: Chia-Lin Chang

Received: 24 August 2021

Accepted: 12 October 2021

Published: 17 October 202

Publisher's Note: MDPI stays neutral with regard to jurisdictional claims in published maps and institutional affiliations.

Copyright: (c) 2021 by the authors. Licensee MDPI, Basel, Switzerland. This article is an open access article distributed under the terms and conditions of the Creative Commons Attribution (CC BY) license (https:// creativecommons.org/licenses/by/ $4.0 /)$.

\begin{abstract}
This study aimed to present the socio-economic conditions, during the COVID-19 pandemic, and their effects on travel decision-making. Data were collected in January and February 2021 using an online questionnaire survey. We compared the data on personal attributes, socio-economic factors, and organizational-related factors of 957 Polish and 181 Nepalese respondents. We found that people would like to travel, even during the COVID-19 pandemic, in both countries; however, tourism in developed countries is expected to revive earlier than in developing countries. Tourists chose natural and rustic areas for travel destinations and family members and friends as travel companions in both countries. Similarly, the use of travel agencies decreased significantly as compared to before the COVID-19 pandemic in both countries. Levels of income and travel motivation were observed to be different between the two countries. Respondents from both countries similarly believed that the overall cost of travel had increased during the pandemic. Therefore, policymakers and authorities of tourism destinations should jointly introduce discounted or subsidized packages targeting family members.
\end{abstract}

Keywords: travel; tourism; pandemic; crisis; COVID-19; respondents; Poland; Nepal; global change; decision-making

\section{Introduction}

On 7 January 2020, the World Health Organization (WHO) announced the coronavirus to be the cause of pneumonia cases in China. The infection became known as Coronavirus Disease 2 (SARS-CoV-2) with severe acute respiratory syndrome, and the illness was termed COVID-19 [1]. After the disease spread to 114 countries, the WHO declared COVID-19 a pandemic on 11 March 2020 [2]. As of 12 August 2021, the WHO recorded 204.6 million patients worldwide had contracted the SARS-CoV-2 virus, of which 185.1 million have recovered and over 4.3 million have died [3,4]. As the world battles the COVID-19 pandemic that has now spread to 206 countries as of this writing, the tourism sector is facing its biggest crisis [1].

The COVID-19 virus has considerably influenced global tourism. Travel restrictions and border closures have been introduced in many countries and regions to limit the spread of COVID-19 [5]. Richter [6] suggests that the emergence or re-emergence of infectious diseases is among the consequences of global tourism and mobility. Urbanization and globalization spreads the virus rapidly [7], and tourism plays a role in exacerbating the ensuing public health crises. Therefore, identifying and quantifying the perceived risks 
and social costs of tourism during the COVID-19 pandemic is crucial to minimize the negative effects of tourism on target cities and regions [3]. Lockdowns have also caused extreme economic difficulties for tourism operators [4], and their attempts to make up for the financial losses may affect customers' willingness to use their services. In this context, exploring travel behavior is important for both developing and developed countries. Tourism enterprises that rely on themselves and innovate to create services and products adjusted to new customer needs and preferences have a better chance to survive [8].

In 2020, the global number of tourist trips dropped by between $60 \%$ and $80 \%[4,9]$. The United Nations World Tourism Organization forecasted the number of tourists to increase in the second half of 2021 as vaccinations in many countries have started, and vaccinations might increase people's confidence to travel [3,9]. However, the new disease variants, which have appeared in many countries, are challenging. The management and sustainability of tourism are important during and post-pandemic. The development of tourism during the pandemic impacts the management of tourism resources so that economic, social, and aesthetic needs are met simultaneously with care for life protection systems and ecological processes [10]. Sustainable tourism during the COVID-19 pandemic is also a management method connecting tourism resources, community members, and other stakeholders [11]. Moreover, maintaining the connections between destinations and tourists primarily depends on the latter's willingness and ability to travel. Exploring their decision-making process helps tourism stakeholders and policymakers devise strategies.

During the COVID-19 pandemic, determining the factors related to decision-making on tourist trips, including the choice of destination, is crucial, especially for marketing strategists. These factors can be grouped into recreational, social (changes in the environment, emotional, participation), cognitive, self-realization, organizational, economic, and health.

Various studies have explored tourism during the COVID-19 pandemic. In the 21st century, the tourism sector is a global business that needs global collaboration. Therefore, comparative studies between countries are necessary to understand the level of willingness to travel and travel decision-making in order to to revive the tourism industry. However, to the best of the authors' knowledge, only one comparative study was conducted between Poland and the U.S. [12]. As this study was conducted between developed countries, other exploratory studies between developed and developing countries are necessary to make sound tourism policies by mitigating the risks in both types of countries [13]. Thus, we chose Nepal and Poland to represent developing and developed countries, respectively, for this study. We chose Poland and Nepal because, first, we wanted to compare the opinions of the respondents between developed and developing countries. Second, the COVID-19 infection in both countries peaked in October and November 2020 and started falling significantly in December and January. This means that both countries faced a similar situation during the pandemic. Based on our descriptive data analysis, we present some policy implications.

\section{Literature Review}

A new trend, virtual tourism, also appears in the tourism industry. Virtual tourism has a strong influence on people's on-site destination choices and can be used as both an effective marketing tool to promote destinations and a platform to sell souvenirs and products [14]. However, we do not discuss virtual tourism in this study because it is beyond our objective.

Different factors influence tourists' travel decisions during the pandemic; however, we supposed that tourists' decision-making was primarily determined by sufficient information availability, travel behaviors, overall travel safety, and other factors [13,15]. Based on these assumptions, we conducted a literature review and integrated the findings in Table 1. 
Table 1. Literature review.

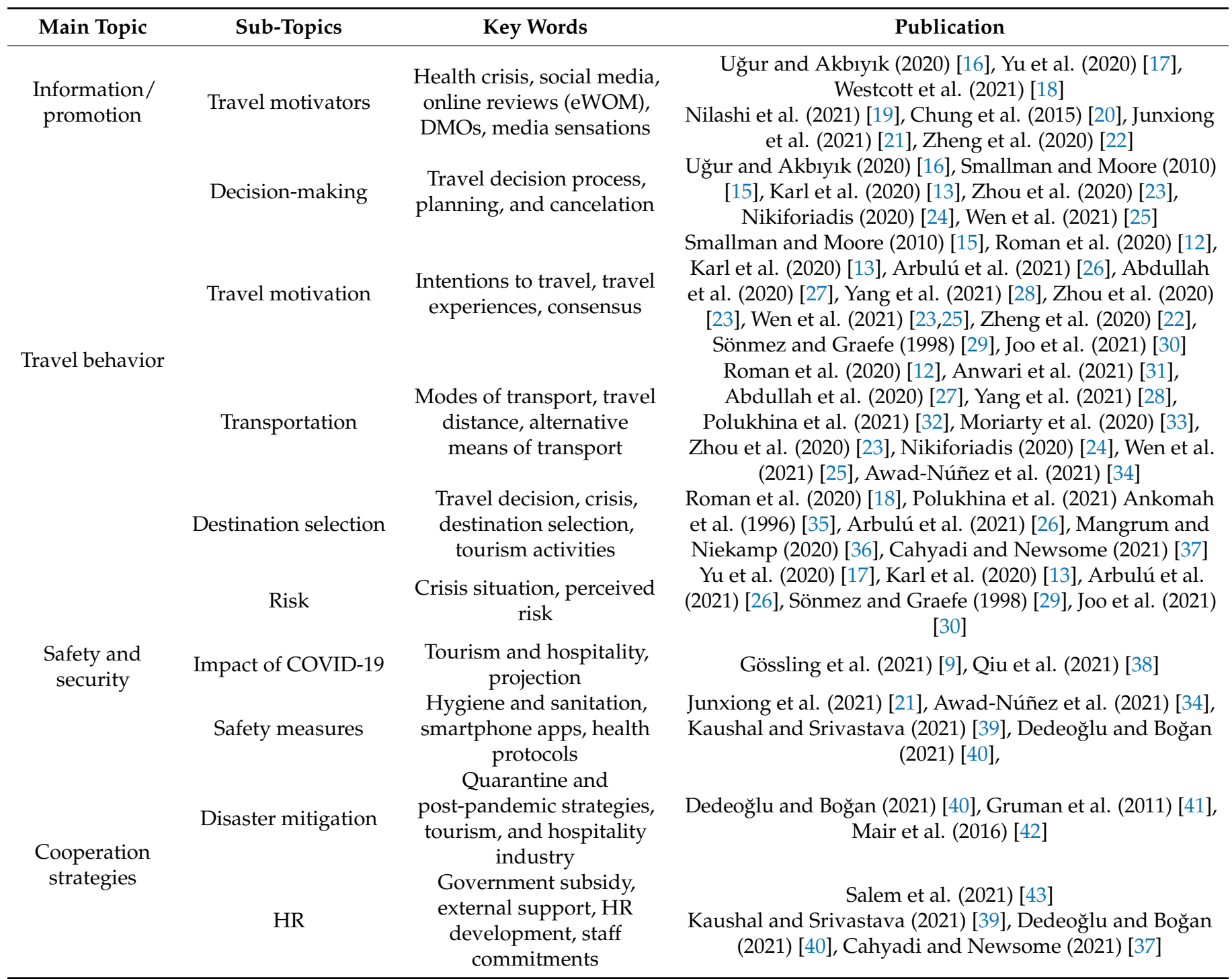

Source: [12-46]. Note: eWOM = electronic word of mouth, DMOs = destination management organizations, HR = human resources.

The spread of COVID-19 and governments' lockdown measures almost stopped most of the tourism industries worldwide. The pandemic caused many of the world's travel destinations to fully (32\%) or partially (34\%) close, resulting in an $87 \%$ decrease in international tourists' arrival in January 2021, when compared with the same month of the previous year [4]. Entry restrictions and travel bans significantly impacted tourism-related stakeholders' socio-cultural, economic, and psychological aspects. As a direct consequence of this situation, many people have either lost their jobs or had reduced working hours [16].

Traveling or staying at home during the pandemic received mixed responses from the public. Some people preferred to stay at home and strictly follow the quarantine measures to reduce the spread and contain the virus [17]. However, others tired of the continued lockdown and felt stressed about staying at home for a long period. The vaccination mandates in many countries are expected to significantly reduce the number of new infections, improve travelers' confidence and thus increase tourism activity $[1,4,18,44]$. In this regard, the roles of recommendation agents, social networking websites, and online reviews, electronic word of mouth, work as motivational factors and encourage visitors to visit destinations by providing real-time information and proper guidance that help people make travel decisions $[17,19]$. Online and media reviews contribute to additional knowledge about destinations, which helps tourists make decisions [15,24]. Salem et al., [43] suggested 
that governments should boost the tourism and hospitality industries and their reputations through established advertising agencies and social networks, especially during the pandemic and post-pandemic.

Tourists' decision-making processes are complex in both ordinary and difficult situations. The process involves determining where to go, why to go, how to go, and with whom to go, among others. It also consists of gaining a deeper understanding of destinations, summarizing growing trends, and confirming individual and collective activities at the destination [15]. Socio-demographic, psychological, and travel aspects and alternative destinations influence the travel decision process $[13,23]$. Social determinants, such as destination choice and tourism involvement, are also directly linked to deciding who accompanies them during travel [12]. Travel decisions are based on assessments of relatively high-risk decisions; that is, nobody knows how wonderful or terrible their trip will be until they experience it $[15,17]$. Because the COVID-19 situation is different from ordinary times, selecting a specific destination demands additional attention and care. The destination characteristics, number of new virus infection cases at the destination, available safety measures, travel risk perception, preferred travel mode, and tourists' attributes, among other factors, directly affect the travel decision.

The choice of destinations is based on negotiation between the traits of the visitors and tourism destinations [13,35]. Many destination management organizations (DMOs) provide intangible destination features, such as information and photographs via social networking sites and destination information channels. If a DMO's official website offers quality information, it will directly affect potential tourists' decision-making processes and destination selections [20]. However, the traveling purpose and destination selection can differ based on the nature of one's job and the necessity to move even during a pandemic. For instance, Mangrum and Niekamp [36] investigated the travel behavior of students during the COVID-19 pandemic and found that those who attended classes prior to early spring vacation were significantly more likely to return to campus after their scheduled spring vacation. Anwari et al. [31] found that because of the nature of their jobs, more men go outside of home for work and shopping, when compared with women. Anwari et al. [31] revealed that men reduced the amount of recreation travel but continued their work-related trips that were recommended by their offices even during the COVID-19 pandemic. In sum, people can freely choose their destinations based on the destinations attractiveness in normal conditions; however, during a pandemic, they had either limited or no choice of destination selection [12,26].

Traveling during a pandemic requires more special considerations, like safety, security, health care facilities etc., than during ordinary times [27]. The COVID-19 outbreak in January 2020 sparked an international public health emergency and challenged national health systems worldwide. The coronavirus became an important risk, particularly to vulnerable members of society, prompting the governments of both developed and developing countries to impose stringent measures to preserve lives and ease the mounting health constraints [45]. At that time, the tourism and hospitality industries had to follow the infection control measures and travel history tracking systems. As a part of the infection control measures, most travel destinations made compulsory the use of masks, sanitization, social distancing, having polymerase chain reaction (PCR) tests, and undergoing quarantine during the travel period [27]. Travelers were required to follow these control measures or were thoroughly monitored throughout their travel to avoid virus infection. Aside from these safety measures, different governments launched smartphone applications to locate one's travel history. These applications function on Bluetooth, GPS, QR codes, and Wi-Fi to gather information. COCOA in Japan, Aarogya Setu in India, StayHomeSafe in Hongkong, NHS in the UK, Hamagen in Israel, WeChat and Alipay in China, Corona Data Donation in Germany, and ProteGO in Poland are some app examples that utilized tracking systems [46].

Moreover, transportation preferences during travel have changed significantly during the pandemic. Specifically, tourists avoid large public transport and prefer using small 
vehicles, which are ideal for either limited numbers of people or family purposes $[12,21,28]$. For instance, more than 30 million people took cruises in the year before the COVID19 pandemic started [33]. At present, many people avoid using cruise ships because they are often a setting for outbreaks of infectious diseases as travelers remain in closed environments and have direct contact with others from diverse destinations [26,33]. By contrast, small vehicles, which are for family purposes or a limited number of people, are used by a growing number of people as a means of transport in many countries [12,28]. For instance, more people used private cars for a trip in Poland during the COVID-19 pandemic [12], and Junxiong et al. [21] forecasted that car travel would increase postpandemic. Multiple studies have found that bike/scooter-sharing is emerging. A study in Greece found that the bike-sharing option became more attractive and important for safety during the pandemic; before the pandemic, people used to ride a bike as a means of entertainment, whereas now, it has become a means of travel. In China, those who like to visit tourist attractions mainly avoid public vehicles and use bikes where possible [25]. In Spain, the willingness to use bike-sharing or kick scooter-sharing increased by more than two-thirds, compared with before COVID-19 [34]. Similarly, bike and public transport were explored as complementary transports to mobilize tourists in U.S. urban environments [28]. In Russian rural tourism, however, contrasting viewpoints were found as compared to other countries. Polukhina et al. [32] found that rural tourists were not stressed by transport and enjoyed a rural lifestyle, ecology, nature rhythm, and social ties during COVID-19. From these findings, we can say that small vehicles are critical, and more people preferred them as a means of transport during the pandemic.

Safety measures at the destinations are another important factor to be considered for a successful travel decision. Because of the sensitive nature of the tourism industry, people try to cancel or postpone their trips as early as possible or almost on the same day when they receive news about the pandemic or any other kind of emergency at the destination [16]. The cancellation of pre-planned itineraries creates negative emotions, such as disappointment and anxiety, among tourists [17]. Alternatively, if tourists feel unwelcomed when visiting a foreign country, the destination may lose the opportunity to host the tourist in the future [22]. In this situation, the performance of tourism enterprises and the destination's image are important to keep tourists motivated, satisfied, and safe throughout their travels. To address the different issues that are already experienced and may occur, Kaushal and Srivastava [36-39] suggested that each tourism and hospitality industry should prepare in advance. A dedicated task force that motivates tourists and ensures their safe and secured travel during the pandemic is necessary [17]. A study of Bulgarian visitors revealed that sanitation and cleanliness determine where tourists stay [40]. Similarly, in other studies, hygiene and sanitation recurred as a sub-theme $[39,41]$.

Peoples' travel decisions during the pandemic are also determined by their travel risk perception; based on the level of perceived risk, they change or postpone their travel plans accordingly [22]. Therefore, tourism and hospitality entrepreneurs should aim to minimize risks to tourists. If a noticed threat cannot be dispelled appropriately, the management of destinations should take countermeasures to promote emotional security [30]. Since news and social media directly impact people's perception of risk and their travel decisions [22], promotion through these channels could be more effective but needs to touch upon the emotional state of potential tourists. A lack of proper and timely communication with the public, media sensationalism, and weak disaster-management plans spoil a destinations image. These factors also change tourists' behavior, especially during crises and disasters $[12,42]$. Moreover, the misleading information flow and media bias also demotivates visitors to travel. For instance, parroted media sensationalism like "Chinese virus carrier" by a political leader in the U.S. affected Chinese travelers' mental well-being. They were even physically attacked in foreign countries [22,24]. Therefore, these kinds of public statements should be discouraged as early as possible. A survey conducted in India presented mixed responses about mass media; whereas some media organizations have raised awareness of the spread of COVID-19, others have downplayed it to be more impartial [39]. 
Therefore, if the media delivers positive information, travel resilience is maintained during and after the pandemic, while negative news can hinder travel to a destination.

Tourism and hospitality businesses depend on visitation patterns; decision-makers make significant efforts to attract tourists to sustain the businesses and increase the industries' effects on multipliers. Travel restrictions at the national or international level, such as border closures, cancelation of events, and quarantine, have hindered tourism and hospitality industries $[9,38]$. However, with vaccination, many countries have opened their tourism destinations and allow visitors to enter with a vaccine passport or a negative PCR certificate. This will increase the number of domestic tourists [44]. A similar case was reported in Indonesia by Cahyadi and Newsome [37]. Furthermore, during the pandemic, nature tourism, like surfing, generated significant economic activity, and surfers were open to supporting and paying for sustainable tourism offers [47].

In summary, from the literature review, we found that many studies were conducted on tourism focusing on the impact of COVID-19 and other different crises. However, exploratory research on tourists' decision-making is lacking. Therefore, we conducted a comparative study between Poland and Nepal.

\section{Methods}

When people's movements and daily lives in both countries were becoming normal amid the COVID-19 pandemic, we conducted diagnostic surveys in both countries in January and February of 2021. The contents of the questionnaire were divided into personal attributes, socio-economic, and organizational factors. Specifically, we asked whether they were willing to travel during COVID-19, mode of transport preferences, reasons for traveling and not traveling, travel agency usage, etc. Some items were measured using five-point Likert scales, whereas destination selections and mode of transport preferences were multiple-choice, and income-related factors were measured continuously.

Respondents were 1012 individuals from Poland (957 qualified for the research) and 362 individuals from Nepal (181 qualified). Respondents were selected using snowball sampling. The survey was conducted using Google Forms, and only the responses of the people who had access to the internet were included in this survey. Owing to the different access of residents to the internet, a similar number of respondents could not be obtained in both countries. Incomplete/insincere responses were excluded from the analysis. Participation was voluntary and only the accumulated data were analyzed and presented. Table 2 presents participants' characteristics.

Table 2. Respondents' characteristics.

\begin{tabular}{|c|c|c|c|}
\hline \multicolumn{2}{|c|}{ Specification } & \multirow{2}{*}{$\frac{\text { Poland (\%) }}{66.2}$} & \multirow{2}{*}{$\frac{\text { Nepal (\%) }}{24.3}$} \\
\hline & Female & & \\
\hline Sex & Male & 33.8 & 75.7 \\
\hline \multirow{5}{*}{ Age (years) } & $<19$ & 0.6 & 1.1 \\
\hline & $20-29$ & 60.9 & 50.8 \\
\hline & $30-39$ & 10.1 & 29.8 \\
\hline & $40-49$ & 21.7 & 12.2 \\
\hline & $\geq 50$ & 6.7 & 6.1 \\
\hline \multirow{4}{*}{ Education level } & Secondary & 3.1 & 5.0 \\
\hline & High school & 36.4 & 21.0 \\
\hline & Bachelor's & 8.2 & 44.7 \\
\hline & $\geq$ Master's & 52.4 & 29.3 \\
\hline
\end{tabular}


Table 2. Cont.

\begin{tabular}{|c|c|c|c|}
\hline \multicolumn{2}{|c|}{ Specification } & \multirow{2}{*}{$\begin{array}{c}\text { Poland }(\%) \\
2.0\end{array}$} & \multirow{2}{*}{$\frac{\text { Nepal (\%) }}{2.8}$} \\
\hline \multirow{5}{*}{ Employment status } & Retired pensioner & & \\
\hline & Manual worker & 3.4 & 1.1 \\
\hline & Professional worker & 42.7 & 35.9 \\
\hline & Student & 47.4 & 22.1 \\
\hline & Business owner & 3.8 & 13.3 \\
\hline \multirow{7}{*}{$\begin{array}{l}\text { Income of one family } \\
\text { member }\end{array}$} & Unemployed & 0.7 & 4.4 \\
\hline & Others & 0.0 & 20.4 \\
\hline & $<$ PLN 1000/NPR 15,000 & 4.7 & 35.4 \\
\hline & $\begin{array}{c}\text { PLN 1001-PLN 1500/NPR } \\
\text { 15,001-NPR 25,000 }\end{array}$ & 14.1 & 13.8 \\
\hline & $\begin{array}{c}\text { PLN 1501-PLN 2500/NPR } \\
\text { 25,001-NPR 35,000 }\end{array}$ & 31.3 & 9.9 \\
\hline & $\begin{array}{c}\text { PLN 2501-PLN 3500/NPR } \\
35,001-N P R 45,000\end{array}$ & 20.2 & 7.2 \\
\hline & >PLN 3500/NPR 45,001 & 29.7 & 33.7 \\
\hline
\end{tabular}

\section{Results}

Figure 1 shows that respondents indicated difficulties related to traveling. Only 20\% of respondents from Poland thought traveling was hard or very hard, whereas $59 \%$ of their Nepalese counterparts thought it was hard or very hard.

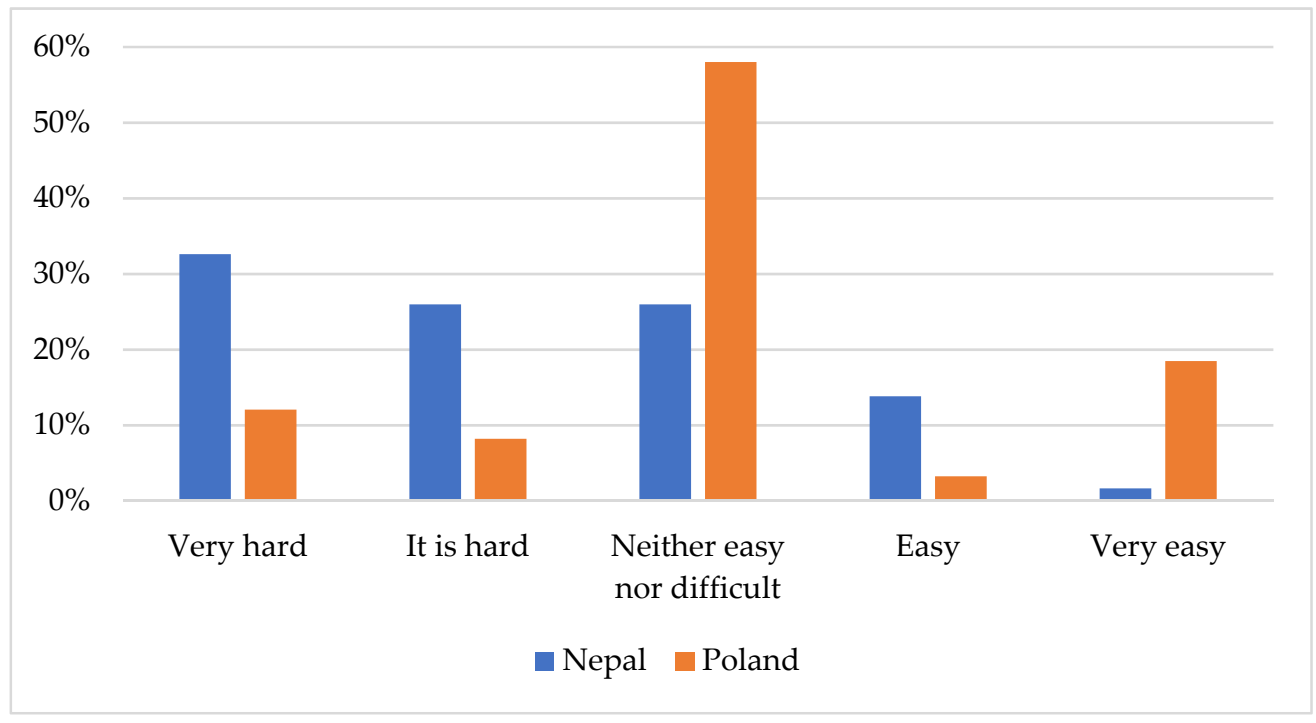

Figure 1. Respondents' traveling opinions during the COVID-19 pandemic by country of origin.

Figure 2 presents respondents' willingness to make travel plans during COVID-19 by the country of origin. More respondents from Nepal than Poland indicated they were not willing to travel during COVID-19. Specifically, only around one-third of the respondents from Nepal were willing to travel, whereas the percentage was almost $80 \%$ from Poland. 


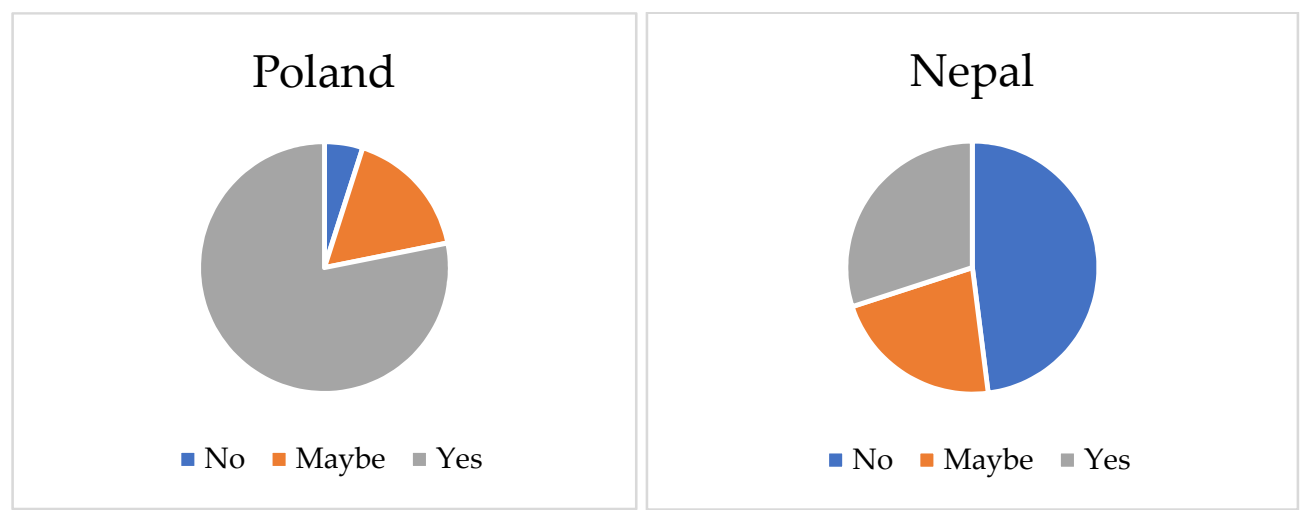

Figure 2. Respondents' willingness to make travel plans during the COVID-19 pandemic by country of origin.

Figure 3 presents the reasons for the lack of willingness of Nepalese respondents to make travel plans during the COVID-19 pandemic. For them, the major reasons were concerns about the virus, being on a limited budget, or having to work.

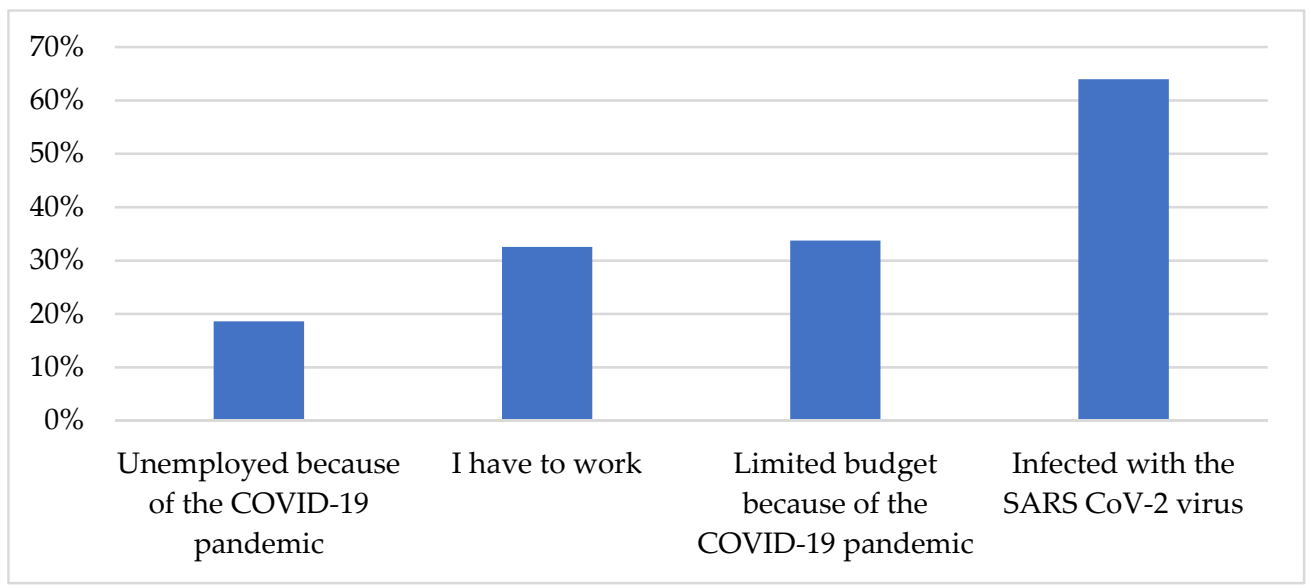

Figure 3. Reasons of respondents from Nepal for their lack of willingness to make travel plans during the COVID-19 pandemic. Multiple selections were allowed.

Figure 4 illustrates respondents' willingness to make travel plans during the COVID19 pandemic depending on income. The different income levels of Nepalese respondents indicate varying willingness to make travel plans; this was not the case for Polish respondents. The percentage of Nepalese respondents who indicated their willingness to travel was lower for those with an income level of $<$ NPR 15,000 (37\%) than those with an income of NPR 25,001-NPR 35,000 (59\%) and NPR 35,001-NPR 45,000 (72\%). In Poland, except those with an income of $<$ PLN 1000 , about $80 \%$ of the respondents in other income categories expressed their willingness to make travel plans in the pandemic. 


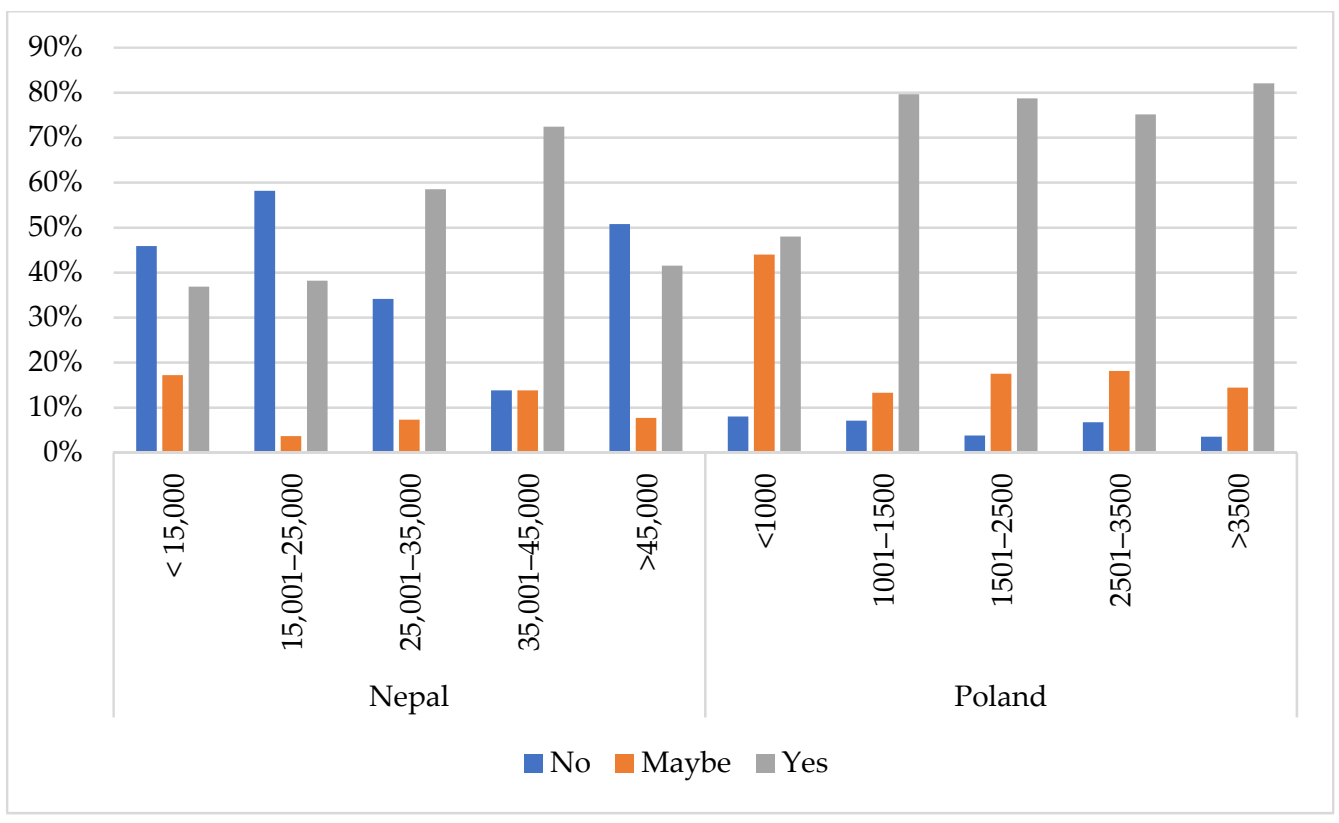

Figure 4. Respondents' willingness to make travel plans in 2021 depending on their income.

Figure 5 shows respondents' preferences for domestic or foreign travel during the COVID-19 pandemic. Most respondents in both countries chose domestic destinations. This may be the result of border closures and suspension of international flights.

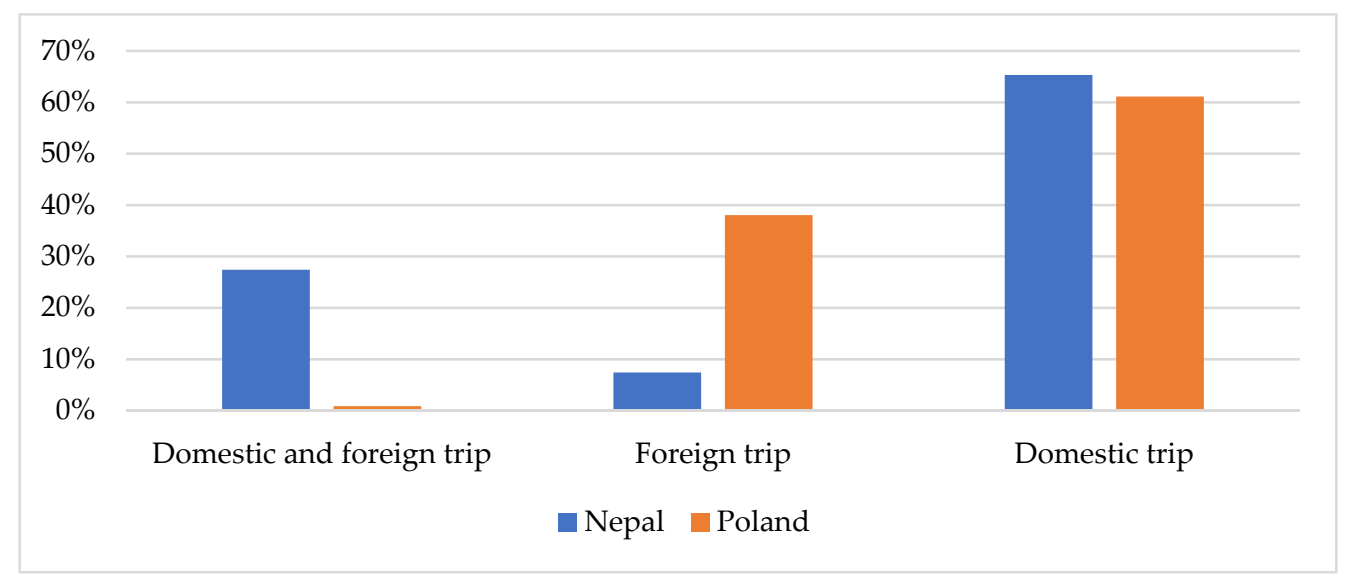

Figure 5. Respondents' choice of domestic or foreign travel during the COVID-19 pandemic by country of origin. Multiple selections were allowed.

Figure 6 displays respondents' use of travel agency offers before and during the COVID-19 pandemic by the country of origin. The number of travel agency users decreased from $76 \%$ to $28 \%$ for Nepal and $60 \%$ to $8 \%$ for Poland. Many factors may influence the choice of destinations during the COVID-19 pandemic. Respondents from both countries were mainly concerned about safety, price, and location in selecting a destination, as can be seen in Figure 7. 


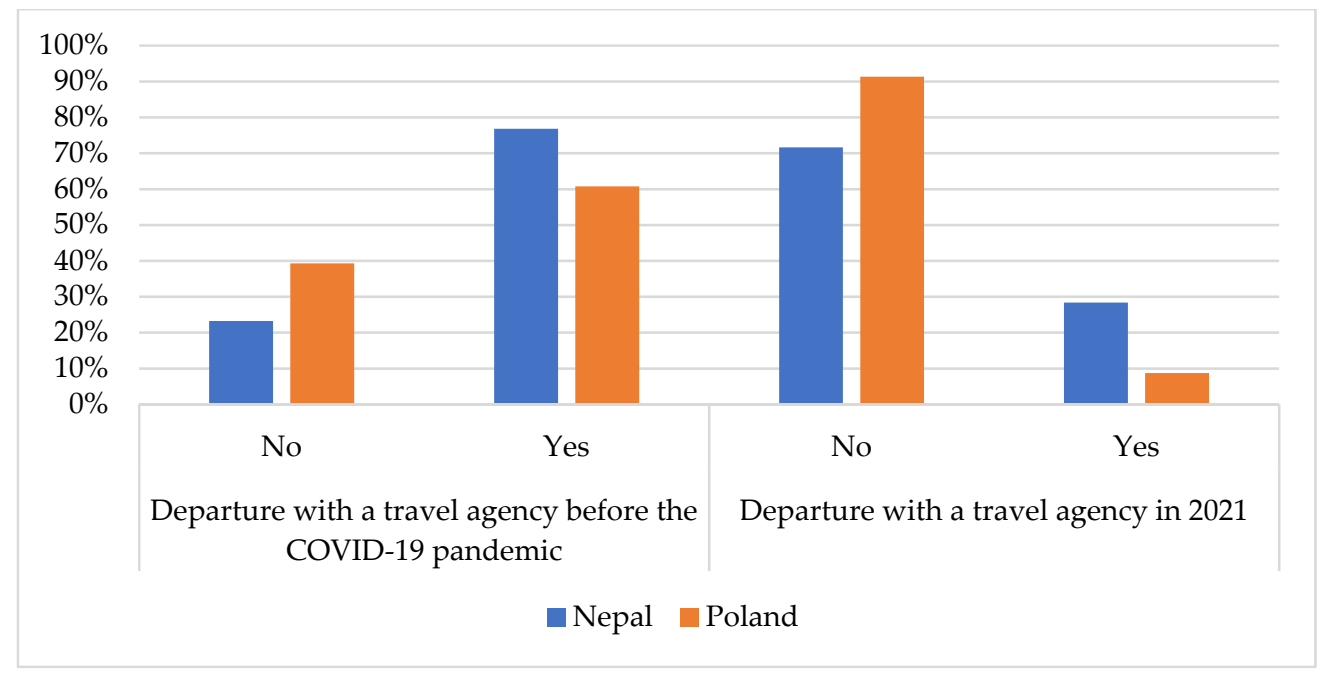

Figure 6. Respondents' use of a travel agency before and during the COVID-19 pandemic by country of origin.

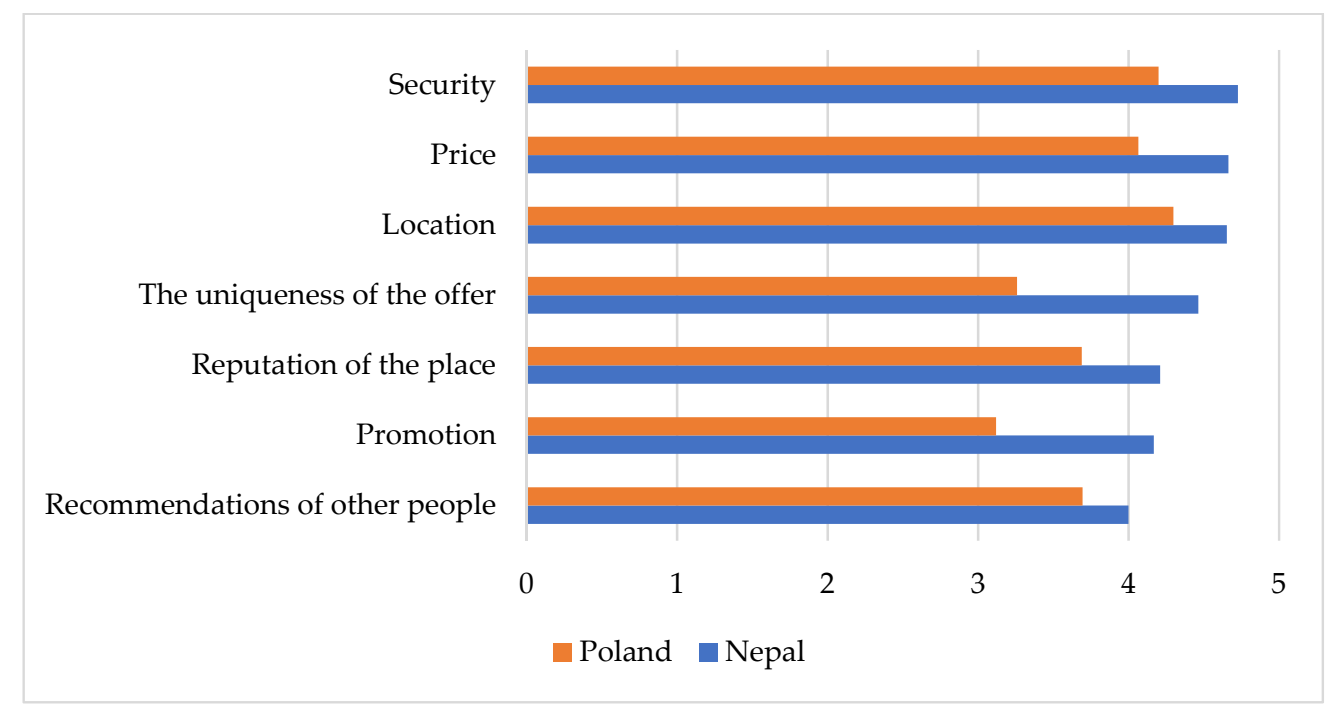

Figure 7. Factors influencing respondents' travel decision-making by country of origin. Multiple selections were allowed.

One factor influencing travel decisions is economic conditions. This study paid attention to travel prices and economic losses of countries where the COVID-19 pandemic was most noticeable. Figure 8 presents the opinion of the respondents on the condition of the overall price in the tourism industry during the COVID-19 pandemic. Results revealed that most respondents from both countries thought overall prices for travel had increased. 


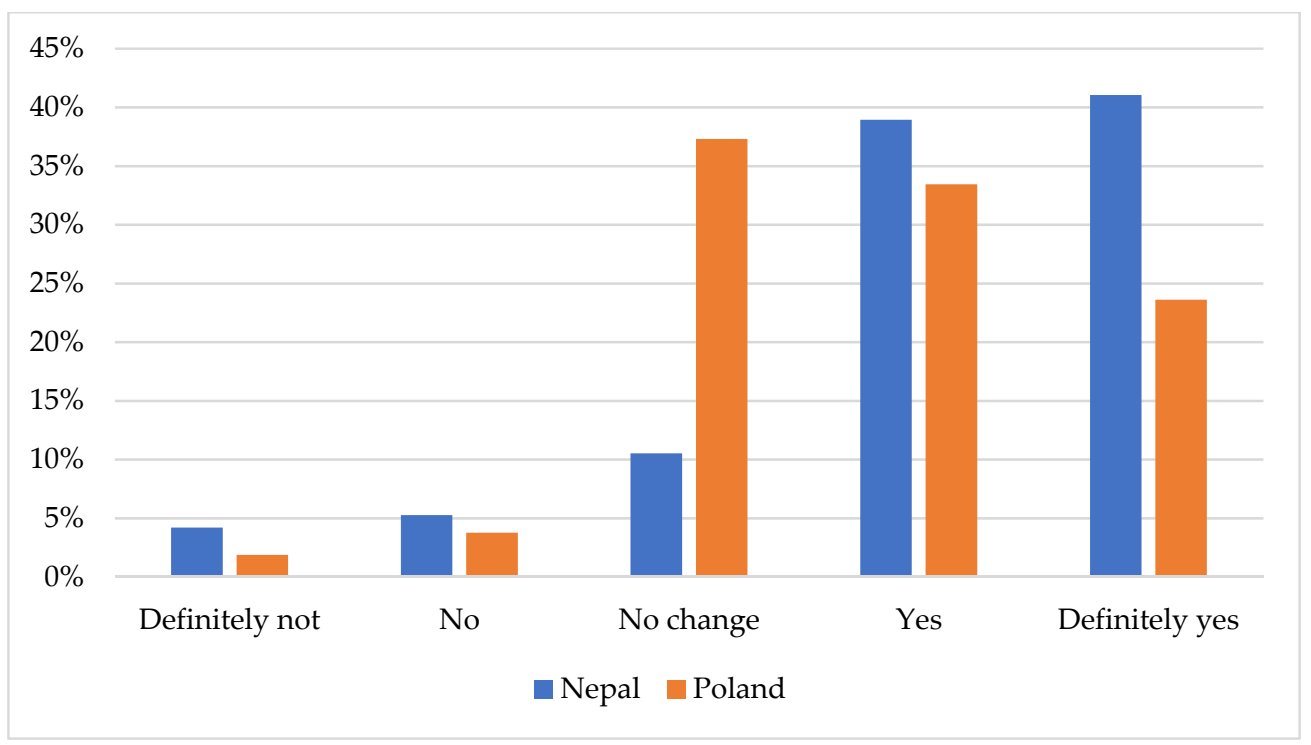

Figure 8. Respondents' opinions concerning whether travel prices had increased during the COVID19 pandemic. Source: own research.

Regarding the mode of transport to use during the pandemic, most Polish and Nepalese respondents preferred personal cars and airplanes, respectively (Figure 9). Rental cars, public buses, and motorcycles were also mentioned.

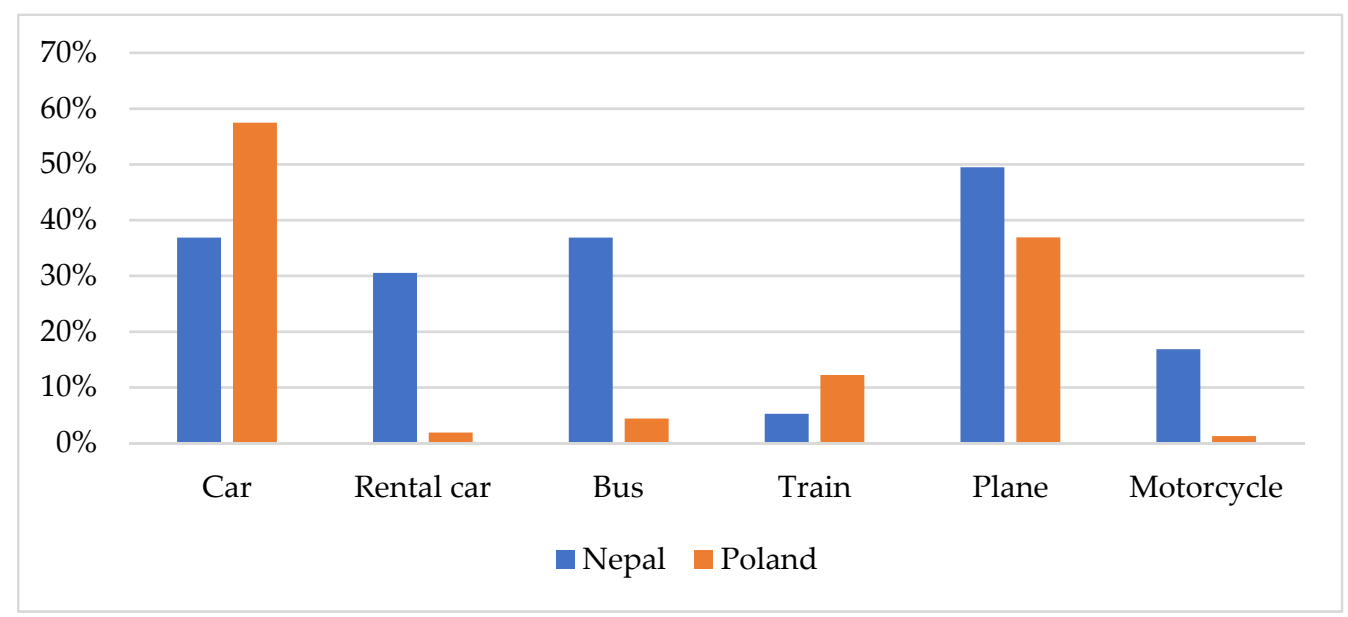

Figure 9. Respondents' preferences for means of transport by country of origin. Multiple selections were allowed.

Figure 10 shows respondents' choice of travel companion. Polish respondents decided to travel mainly with a partner/family members or friends, and $42 \%$ of Nepalese respondents decided to travel with their family. This result is contradictory with previous studies, indicating that people were willing to travel with friends or with a spouse [12]. 


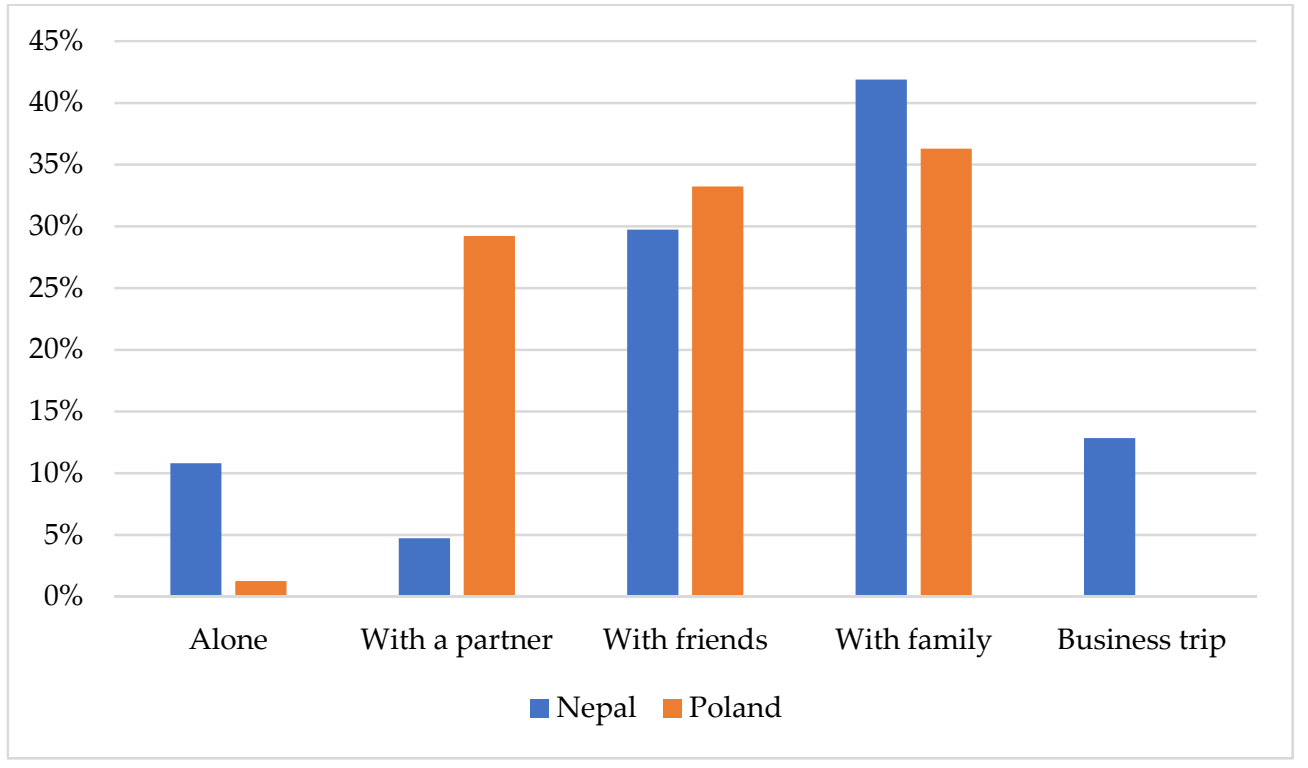

Figure 10. Respondents' choice of travel companions in 2021 by country of origin. Multiple selections were allowed.

More affluent people preferred domestic trips in both countries. Most Polish respondents preferred staying at hotels or boarding houses near the sea and in the mountains; similarly, most Nepalese respondents preferred staying at hotels or with family in the mountains and rural villages (Figure 11).

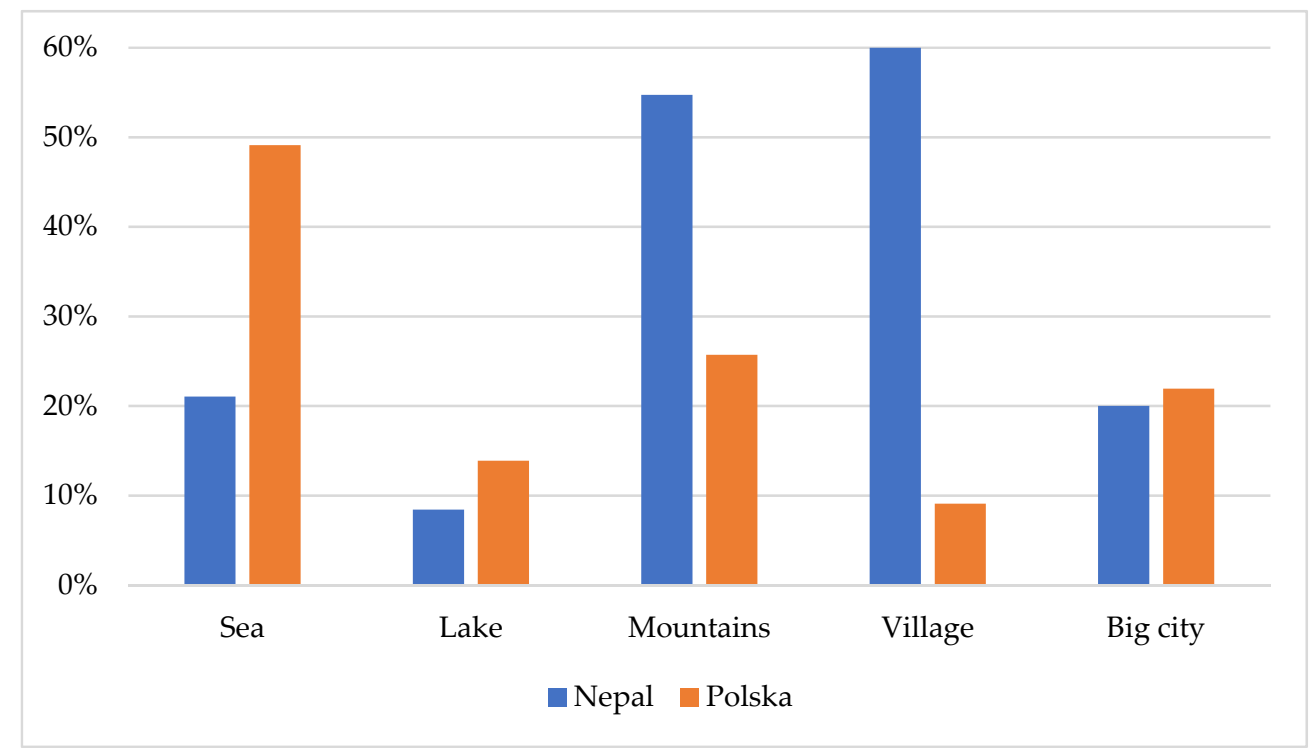

Figure 11. Respondents' choice of tourist destination by country of origin. Multiple selections were allowed.

Nearly $50 \%$ of Polish respondents preferred to stay at the seaside, and about $25 \%$ chose mountains and agritourism. By contrast, $55 \%$ of Nepalese respondents preferred visiting mountains and and $60 \%$ preferred rural villages. These results are understandable in the COVID-19 pandemic because people choose rural areas to feel safe, compared with more crowded destinations in urban areas [47,48]. 


\section{Discussions and Conclusions}

This study investigated the factors related to travel decision-making, during the COVID-19 pandemic, of people from Poland and Nepal. We compared their personal attributes, socio-economic conditions, and organizational-related situations. The major findings are summarized as follows.

More than three-fourths of Polish respondents expressed their willingness to travel during the COVID-19 pandemic, whereas almost half of the Nepalese respondents said they had no plan. These findings indicate that people from developed countries would travel even during the pandemic because they have comparatively easier access to medical facilities in case of emergency than those in developing countries. However, in addition to the economic factors, people are afraid to travel in developing countries because of the weak health-related infrastructure and low capacity of the government to cope with the pandemic. Therefore, we suggest that governments, especially the ones of destination countries, ensure safety measures like disinfection, masking, and social distancing when welcoming tourists. Additionally, the availability of vaccination increases the confidence of the public to travel [7]. Based on the differences in willingness to travel between Polish and Nepalese respondents, we generalize that tourism in developed countries will bounce back earlier, as compared to developing countries, as more people in the former are willing to travel even in the pandemic, compared with those in the latter.

Annual income levels and travel plans in 2021 were observed to be different between Poland and Nepal. In the case of Nepal, only a limited number of respondents with a lower annual income level showed interest in traveling and vice versa. However, in Poland, it was different; respondents with a lower income level said they wanted to travel during COVID-19. These results suggest that subsidized or discounted tourism packages focusing on tourists originating from developing countries are necessary.

Respondents from both countries mentioned that the overall cost of travel has increased. Therefore, policymakers and authorities of tourism destinations should jointly introduce discounted or subsidized packages targeting family members to revive tourism. Moreover, interest in using travel agencies during the COVID-19 pandemic decreased, as compared with pre-pandemic interest. In this regard, governments and travel agencies should work together to increase the quality of human resources. Trained and highly skilled workers can work not only in the crisis situation, but also in new tourism destinations in the future $[17,49]$.

Regarding travel companions, we observed that family members were mostly preferred. Similarly, respondents from both countries liked to choose more natural and rustic tourism destinations. From these results, we can say that people feel safer traveling with family members and touring less-crowded destinations. People from both developed and developing countries take tourism as an opportunity to release family stress during the pandemic by visiting nature.

Recommendations for tourist facilities during the COVID-19 pandemic (e.g., hotels, guesthouses, etc.) are also an important issue. It is important for locations to develop a health and safety checklist, e.g., floor plan, room sizes, and bed capacity. Hotel owners should provide a list of health and safety issues during the COVID-19 pandemic. The establishment of isolation hotels as alternative care settings and the ability to rapidly adapt to the needs of their guest population are essential to help address the COVID-19 pandemic. Over time, the isolation hotel program may evolve to serve, for example, pregnant women and infants, and remove barriers to guests, such as childcare, domestic help, and companion pets. Developing program operations should include quality assurance and performance-improvement measures, including the following: asking guests for feedback on their hotel stay and enhancing the guest experience by considering access to indoor and outdoor recreational spaces and activities; providing additional food options, including takeaway; and offering additional in-room entertainment options, including premium cable channels [50]. 
The hospitality industry should define crisis management practices, especially when a crisis becomes worse or lasts longer than expected. In addition, appropriate crisis management practices are time-dependent. Comparing the changes made in the initial stage of the COVID-19 pandemic with the present stage is an ongoing study that can contribute to understanding the conditions of the decline in crisis management for the hospitality industry. Hotel marketing practices should include preparing promotional plans. Hotels could even develop and sell special peace packages offering future discounts to increase cash flow and accelerate crisis recovery [51].

It is also important to measure the body temperature of hotel guests and educate workers about how to prevent a pandemic $[52,53]$. Appropriate training should be organized for staff to take precautionary measures during an epidemic. Training should include epidemic communication guidelines, standard precautions, infection control, and hygiene techniques. Providing training can help reduce infection rates while building a hotel's reputation [54].

Although we explored many factors related to travel decision-making, this study has limitations. It was conducted using Google Forms, and only the responses of the people who had access to the internet were included. We could not collect information on social distancing, vaccination rates, and PCR tests, which affect travel decisions; therefore, these should be addressed in future studies. This study dealt with the demand side of tourism; future studies should focus on the supply-side with the following research questions:

- What is the impact of the COVID-19 pandemic on the tourism labor market?

- Will the COVID-19 virus lead to a radical transformation of the tourism sector?

- How might the tourism and hospitality industries respond to such changes in the future?

- How can we mitigate similar future public health crises?

Author Contributions: Conceptualization, M.R. (Michał Roman), M.R. (Monika Roman), K.B. and P.G.; methodology, M.R. (Michał Roman), M.R. (Monika Roman), K.B. and P.G.; software, M.R. (Michał Roman), M.R. (Monika Roman), K.B. and P.G.; validation, M.R. (Michał Roman), M.R. (Monika Roman), K.B. and P.G.; formal analysis, M.R. (Michał Roman), M.R. (Monika Roman); investigation, M.R. (Michał Roman), M.R. (Monika Roman), K.B. and P.G.; resources, M.R. (Michał Roman), M.R. (Monika Roman), K.B. and P.G.; data curation, M.R. (Michał Roman), M.R. (Monika Roman), K.B. and P.G.; writing—original draft preparation, M.R. (Michał Roman), M.R. (Monika Roman), K.B. and P.G.; writing-review and editing, M.R. (Michał Roman), M.R. (Monika Roman), K.B. and P.G.; visualization, M.R. (Michał Roman); supervision, M.R. (Michał Roman); project administration, M.R. (Michał Roman); funding acquisition, M.R. (Michał Roman), K.B. and M.R. (Monika Roman). All authors have read and agreed to the published version of the manuscript.

Funding: This research was funded by the Japan Society for the Promotion of Science under Grantin-Aid for JSPS Fellows no: JP20J11833.

Institutional Review Board Statement: Not applicable.

Informed Consent Statement: Not applicable.

Data Availability Statement: Not applicable.

Conflicts of Interest: The authors declare no conflict of interest.

\section{References}

1. WHO. Coronavirus Disease (COVID-19) Outbreak Situation; World Health Organization: Geneva, Switzerland. Available online: https:/ / www.who.int/emergencies/diseases/novel-coronavirus-2019 (accessed on 18 May 2021).

2. Correa-Martínez, C.L.; Kampmeier, S.; Kümpers, P.; Schwierzeck, V.; Hennies, M.; Hafezi, W.; Kühn, J.; Pavenstädt, H.; Ludwig, S.; Mellmann, A. A pandemic in times of global tourism: Superspreading and Exportation of COVID-19 cases from a ski area in Austria. J. Clin. Microbiol. 2020, 58, 1-3. [CrossRef]

3. Forbes. Available online: https://www.forbes.pl/wiadomosci/koronawirus-w-polsce-i-na-swiecie-aktualna-mapa-zachorowanilu-jest-chorych-ile-osob/yl0meqc (accessed on 12 August 2021).

4. UNWTO. Available online: https: / / www.unwto.org/tourism-covid-19 (accessed on 12 August 2021). 
5. Al Jazeera Coronavirus: Travel Restrictions, Border Shutdowns by Country. Available online: https://www.aljazeera.com/news/ 2020/03/coronavirus-travel-restrictions-border-shutdowns-country-200318091505922.html (accessed on 18 May 2021).

6. Richter, L.K. International tourism and its global public health consequences. J. Travel Res. 2003, 41, 340-347. [CrossRef]

7. Hilsenrath, J. Global viral outbreaks like coronavirus, once rare, will become more common. The Wall Street Journal, 6 March 2020.

8. Sheresheva, M.; Efremova, M.; Valitova, L.; Polukhina, A.; Laptev, G. Russian tourism enterprises' marketing innovations to meet the COVID-19 challenges. Sustainability 2021, 13, 3756. [CrossRef]

9. Gossling, S.; Scott, D.; Hall, M. Pandemics, tourism and global change: A rapid assessment of COVID-19. J. Sustain. Tour. 2020, 29, 1-20. [CrossRef]

10. Halme, M. Learning for sustainable development in tourism networks. Bus. Strategy Environ. 2001, 10, 100-114. [CrossRef]

11. Sharpley, R. Tourism and sustainable development exploring the theoretical divide. J. Sustain. Tour. 2000, 8, 1-19. [CrossRef]

12. Roman, M.; Niedziółka, A.; Krasnodębski, A. Respondents' involvement in tourist activities at the time of the COVID-19 Pandemic. Sustainability 2020, 12, 9610. [CrossRef]

13. Karl, M.; Muskat, B.; Ritchie, B.W. Which travel risks are more salient for destination choice? An examination of the tourist's decision-making process. J. Destin. Mark. Manag. 2020, 18, 100487. [CrossRef]

14. Lu, J.; Xiao, X.; Xu, Z.; Wang, C.; Zhang, M.; Zhou, Y. The potential of virtual tourism in the recovery of tourism industry during the COVID-19 pandemic. Curr. Issues Tour. 2021, 1-17. [CrossRef]

15. Smallman, C.; Moore, K. Process studies of tourists' decision-making. Ann. Tour. Res. 2021, 37, 397-422. [CrossRef]

16. Uğur, N.G.; Akbıyık, A. Impacts of COVID-19 on global tourism industry: A cross-regional comparison. Tour. Manag. Perspect. 2020, 36, 100744. [CrossRef]

17. Yu, M.; Li, Z.; Yu, Z.; He, J.; Zhou, J. Communication related health crisis on social media: A case of COVID-19 outbreak. Curr. Issues Tour. 2020, 46, 2699-2705. [CrossRef]

18. Westcott, B.; Wang, S. China is Experiencing a Rural Tourism Boom Amid the Covid-19 Pandemic; CNN: Atlanta, GA, USA, 2021.

19. Nilashi, M.; Asadi, S.; Minaei-Bidgoli, B.; Ali Abumalloh, R.; Samad, S.; Ghabban, F.; Ahani, A. Recommendation agents and information sharing through social media for coronavirus outbreak. Telemat. Inform. 2021, 61, 101597. [CrossRef]

20. Chung, N.; Lee, H.; Lee, S.J.; Koo, C. The influence of tourism website on tourists' behavior to determine destination selection: A case study of creative economy in Korea. Technol. Forecast. Soc. Chang. 2015, 96, 130-143. [CrossRef]

21. Li, J.; Nguyen, T.H.H.; Coca-Stefaniak, J.A. Coronavirus impacts on post-pandemic planned travel behaviours. Ann. Tour. Res. 2020, 86, 102964. [CrossRef]

22. Zheng, Y.; Goh, E.; Wen, J. The effects of misleading media reports about COVID-19 on Chinese tourists' mental health: A perspective article. Anatolia 2020, 31, 337-340. [CrossRef]

23. Zhou, S.; Han, L.; Liu, P.; Zheng, Z.J. Global health governance for travel health: Lessons learned from the coronavirus disease 2019 (COVID-19) outbreaks in large cruise ships. Glob. Health J. 2020, 4, 133-138. [CrossRef] [PubMed]

24. Nikiforiadis, A.; Ayfantopoulou, G.; Stamelou, A. Assessing the impact of COVID-19 on bike-sharing usage: The case of Thessaloniki, Greece. Sustainability 2020, 12, 8215. [CrossRef]

25. Wen, J.; Kozak, M.; Yang, S.; Liu, F. COVID-19: Potential effects on Chinese citizens' lifestyle and travel. Tour. Rev. 2021, 76, 74-87. [CrossRef]

26. Arbulú, I.; Razumova, M.; Rey-Maquieira, J.; Sastre, F. Can domestic tourism relieve the COVID-19 tourist industry crisis? The case of Spain. J. Destin. Mark. Manag. 2021, 20, 100568.

27. Abdullah, M.; Dias, C.; Muley, D.; Shahin, M. Exploring the impacts of COVID-19 on travel behavior and mode preferences. Transp. Res. Interdiscip. Perspect. 2021, 8, 100255.

28. Yang, Y.; Jiang, L.; Zhang, Z. Tourists on shared bikes: Can bike-sharing boost attraction demand? Tour. Manag. 2021, 86, 104328. [CrossRef]

29. Sönmez, S.F.; Graefe, A.R. Determining future travel behavior from past travel experience and perceptions of risk and safety. J. Travel Res. 1998, 37, 171-177. [CrossRef]

30. Joo, D.; Xu, W.; Lee, J.; Lee, C.K.; Woosnam, K.M. Residents' perceived risk, emotional solidarity, and support for tourism amidst the COVID-19 pandemic. J. Destin. Mark. Manag. 2021, 19, 100553.

31. Anwari, N.; Tawkir Ahmed, M.; Rakibul Islam, M.; Hadiuzzaman, M.; Amin, S. Exploring the travel behavior changes caused by the COVID-19 crisis: A case study for a developing country. Transp. Res. Interdiscip. Perspect. 2021, 9, 100334.

32. Polukhina, A.; Sheresheva, M.; Efremova, M.; Suranova, O.; Agalakova, O.; Antonov-Ovseenko, A. The concept of sustainable rural tourism development in the face of COVID-19 crisis: Evidence from Russia. J. Risk Financ. Manag. 2021, 14, 38. [CrossRef]

33. Moriarty, L.F.; Plucinski, M.M.; Marston, B.J.; Kurbatova, E.V.; Knust, B.; Murray, E.L.; Pesik, N.; Rose, D.; Fitter, D.; Kobayashi, M.; et al. Public health responses to COVID-19 outbreaks on cruise ships-worldwide, February-March 2020. In MMWR. Morb. Mortal. Wkly. Rep. 2020, 69, 347-352. [CrossRef]

34. Awad-Núñez, S.; Julio, R.; Gomez, J.; Moya-Gómez, B.; González, J.S. Post-COVID-19 travel behaviour patterns: Impact on the willingness to pay of users of public transport and shared mobility services in Spain. Eur. Transp. Res. Rev. 2021, 13, 1-18. [CrossRef]

35. Ankomah, P.K.; Crompton, J.L.; Baker, D. Influence of cognitive distance in vacation choice. Ann. Tour. Res. 1996, 23, 138-150. [CrossRef] 
36. Mangrum, D.; Niekamp, P. JUE Insight: College student travel contributed to local COVID-19 spread. J. Urban Econ. 2020, in press, 103311. [CrossRef]

37. Cahyadi, H.S.; Newsome, D. The post COVID-19 tourism dilemma for geoparks in Indonesia. Int. J. Geoheritage Parks 2021, 9 , 199-211. [CrossRef]

38. Qiu, R.T.R.; Wu, D.C.; Drospy, V.; Petit, S.; Pratt, S.; Ohe, Y. Visitors arrivals forecasts amid COVID-19: A perspective from the Asia and Pacific Team. Ann. Tour. Res. 2021, 88, 103155. [CrossRef]

39. Kaushal, V.; Srivastava, S. Hospitality and tourism industry amid COVID-19 pandemic: Perspectives on challenges and learnings from India. Int. J. Hosp. Manag. 2021, 92, 102707. [CrossRef] [PubMed]

40. Dedeoğlu, B.B.; Boğan, E. The motivations of visiting upscale restaurants during the COVID-19 pandemic: The role of risk perception and trust in government. Int. J. Hosp. Manag. 2021, 95, 102905. [CrossRef]

41. Gruman, J.A.; Chhinzer, N.; Smith, G.W. An exploratory study of the level of disaster preparedness in the Canadian hospitality industry. Int. J. Hosp. Tour. Adm. 2011, 12, 43-59. [CrossRef]

42. Mair, J.; Ritchie, B.W.; Walters, G. Towards a research agenda for post-disaster and post-crisis recovery strategies for tourist destinations: A narrative review. Curr. Issues Tour. 2016, 19, 1-26. [CrossRef]

43. Salem, I.E.; Elbaz, A.M.; Elkhwesky, Z.; Ghazi, K.M. The COVID-19 pandemic: The mitigating role of government and hotel support of hotel employees in Egypt. Tour. Manag. 2021, 85, 104305. [CrossRef]

44. UNWTO. UNWTO World Tourism Barometer and Statistical Annex. UNWTO World Tour. Barom. 2021, 19, 1-42.

45. Kizys, R.; Tzouvanas, P.; Donadelli, M. From COVID-19 herd immunity to investor herding in international stock markets: The role of government and regulatory restrictions. Int. Rev. Financ. Anal. 2021, 74, 101663. [CrossRef]

46. Jinfeng, L.; Guo, X. COVID-19 contact-tracing apps: A survey on the global deployment and challenges. arXiv 2020, arXiv:2005.03599.

47. Mach, L.; Ponting, J. Establishing a pre-COVID-19 baseline for surf tourism: Trip expenditure and attitudes, behaviors and willingness to pay for sustainability. Ann. Tour. Res. Empir. Insights 2021, 2, 100011. [CrossRef]

48. Roman, M.; Grudzien, P. The essence of agritourism and its profitability during the coronavirus (COVID-19) pandemic. Agriculture 2021, 11, 458. [CrossRef]

49. Bhatta, K.; Ohe, Y.; Ciani, A. Which human resources are important for turning agritourism potential into reality? SWOT analysis in rural Nepal. Agriculture 2020, 10, 197. [CrossRef]

50. Jordan-Martin, N.C.; Madad, S.; Alves, L.; Wang, J.; O'Gere, L.; Smith, Y.G.; Pressman, M.; Shure, J.A.; Cosmi, M. Isolation hotels: A community-based intervention to mitigate the spread of the COVID-19 pandemic. Health Secur. 2020, 18, 377-382. [CrossRef]

51. Lai, I.K.W.; Wong, J.W.C. Comparing crisis management practices in the hotel industry between initial and pandemic stages of COVID-19. Int. J. Contemp. Hosp. Manag. 2020, 32, 3135-3156. [CrossRef]

52. Baum, T.; Hai, N.T.T. Hospitality, tourism, human rights and the impact of COVID-19. Int. J. Contemp. Hosp. Manag. 2020, 32, 2397-2407. [CrossRef]

53. Sio-Chong, U.; So, Y.C. The impacts of financial and non-financial crises on tourism: Evidence from Macao and Hong Kong. Tour. Manag. Perspect. 2020, 33, 100628.

54. Zhao, Y.; Xu, H. Chinese public attention to COVID-19 epidemic: Based on social media: Observational descriptive study. J. Med. Internet Res. 2020, 22, e18825. [CrossRef] [PubMed] 